\title{
Composition and structure of parasite communities in white bream Blicca bjoerkna from Lake Büyük Akgöl, Sakarya-Turkey
}

\section{Sakarya Büyülk Akgöl'den tahta balığı Blicca bjoerkna’da parazit komünitenin kompozisyon ve yapısı}

\author{
Ayçanaz Altan1 (D) Erhan Soylu2*
}

'Fisheries Department, Institute for Graduate Studies in Pure and Applied Sciences, Marmara University, Göztepe, TR-34722 Kadıköy, Istanbul, Turkey 2Fisheries Department, Vocational School of Technical Sciences, Marmara University, Göztepe, TR-34722 Kadıköy, Istanbul, Turkey

* Corresponding author: esoylu@marmara.edu.tr

How to cite this paper:

Altan, A. \& Soylu, E. (2018). Composition and structure of parasite communities in white bream Blicca bjoerkna from Lake Büyük Akgöl, Sakarya-Turkey. Ege Journal Fisheries and Aquatic Sciences, 35(2), 199-206. DOI:10.12714/egejfas.2018.35.2.14

\begin{abstract}
No data on the parasites of Blicca bjoerkna have been reported to date from Lake Büyük Akgöl. Therefore, the current study aimed to investigate the composition and diversity of parasite component and infra-communities in this cyprinid fish from hypereutrophic Lake Büyük Akgöl. A total of 61 B. bjoerkna were examined between July 2016 and June 2017. All fishes were hosts to at least one parasite species from the following taxa: Trichodina sp., Epistylis sp. (Protozoa); Myxobolus sp. (Myxozoa); Dactylogyrus sphyrna, D. cornu, D. cornoides, D. distinguendus and Paradiplozoon homoion (Monogenea); Caryophyllaeus laticeps and Cestoda gen. sp. (Cestoidea); Diplostomum sp., Thylodelphys clavata and Posthodiplostomum cuticola (Digenea); Piscicola geometra (Hirudinea); Glochidium sp. (Mollusca) and Argulus foliaceus (Crustacea). Dominant species in the component community were Diplostomum sp., D. cornoides, and D. cornu. Totally 2063 metazoan parasite individuals were collected. Parasite infra-communities of $B$. bjoerkna infected 1-10 species and the mean species richness found was 5.3. The mean metazoan parasite diversity (Shannon's H index) was 2.08 and the Shannon-Wiener Evenness (E) had a mean value of 0.81. Identified parasite species in B.bjoerkna were the first records from Lake Büyük Akgöl.
\end{abstract}

Keywords: Parasite communities, Blicca bjoerkna, Lake Büyük Akgöl

Öz: Bugüne kadar Büyük Akgöl'den Blicca bjoerkna'da bulunan parazitler hakkında herhangi bir veri bildirilmemiş̧tir. Bu nedenle çalışmamız, hiperöytrofik karakterdeki Büyük Akgöl'de yaşayan bu cyprinid balığın parazit component ve infra-komünitesinin kompozisyon ve çeşitliliğinin araştııımasını amaçlamış ve Temmuz 2016 ile Haziran 2017 arasında toplam 61 B. bjoerkna ile çalışılmıştır. Tüm balıklar aşağıda belirtilen taksonlardan en az bir parazit türüne konak olmuştur: Trichodina sp., Epistylis sp. (Protozoa); Myxobolus sp. (Myxozoa); Dactylogyrus sphyrna, D. cornu, D. cornoides, D. distinguendus ve Paradiplozoon homoion (Monogenea); Caryophyllaeus laticeps ve Cestoda gen. sp. (Cestoidea); Diplostomum sp., Thylodelphys clavata ve Posthodiplostomum cuticola (Digenea); Piscicola geometra (Hirudinea); Glochidium sp. (Mollusca) ve Argulus foliaceus (Crustacea). Komponent komünitedeki baskın türler Diplostomum sp., $D$. cornoides ve $D$. cornu olarak belirlenmiş ve toplam olarak 2063 adet çok hücreli parazit bireyi toplanmışırı. B. bjoerkna'nın parazit infra komunitesinin 1-10 tür tarafından enfekte edildiği ve ortalama tür zenginliğinin 5.3 olduğu belirlenmiştir. Çok hücreli parazit ortalama çeşitlilği (Shannon's H index) 2.08 ve ShannonWiener Evenness (E) ortalama değeri 0.81 olarak bulunmuştur. B.bjoerkna'da teşhis edilen parazit türleri Büyük Akgöl için ilk kayıtlardır.

Anahtar kelimeler: Parazit komünite, Blicca bjoerkna, Büyük Akgöl

\section{INTRODUCTION}

Lake Büyük Akgöl is considered hypereutrophic due to high nutrient input from domestic sources and agricultural activities (Şahin et al., 2013). During the summer months, the entire lake area is covered by sixteen species of submerged, floating and emergent macrophytes associated with excessive blooms of planktonic algae (Altınsaçlı et al., 2013). This shallow lake with a mean depth of $1.5 \mathrm{~m}$ is located in the north-west region of Turkey. Fish species examined in the current study Blicca bjoerkna is a European species of freshwater fish of the family Cyprinidae. White bream was zoogeographically introduced into Turkey from the Western Thrace region, and it spreads widely in inland waters and lagoons of Marmara and Black Sea regions in Turkey (Geldiay and Balık, 1988). B. bjoerkna are exclusively bottom feeders and their diet depends largely on benthic invertebrates and insect larvae. There are some papers on parasites of B. bjoerkna in Turkey (Akıncı,1999; Öztürk, 2001; Soylu, 2006, 2012; Selver, 2010; Akmirza and Yardımcl, 2014). The description of the composition and structure of the fish parasite communities was based on species richness and diversity. Diversity is one of the most important community attributes, and measured using both species richness and species evenness. Species richness is the simplest measure of 
diversity and does not consider whether abundances are evenly distributed among species (Krebs, 1999; Stirling and Wilsey, 2001). Therefore relative abundance of each parasite species or species evenness is a key component of the structure of any parasite community (Poulin, 1996). Index of dominance is another diversity indice and use to assess the magnitude of the numerical supremacy of the top-ranked species in the parasite community (Poulin et al., 2008). In the present study we calculated species richness, ShannonWiener Index, Shannon-Wiener Evenness and Simpson's Diversity as some diversity indices to determine composition and structure of parasite community of $B$. bjoerkna.

This study represents the first investigation of parasite fauna of white bream from Lake Büyük Akgöl.

\section{MATERIALS AND METHODS}

\section{Study area}

Lake Büyük Akgöl is located in Western Black Sea Region of Turkey $\left(41^{\circ} 02^{\prime} 52.97^{\prime \prime} \mathrm{N}\right.$ and $\left.30^{\circ} 33^{\prime} 49.61^{\prime \prime} \mathrm{E}\right)$, at an altitude of $58 \mathrm{~m}$ above sea level. Büyük Akgöl is a freshwater lake of a eutrophic character and with a mean depth of $1.5 \mathrm{~m}$, maximum depth of $5 \mathrm{~m}$ and surface area of $3.5 \mathrm{~km}^{2}$ (Altınsaçlı et al., 2013). Mean annual surface water temperature in the lake is $16.5^{\circ} \mathrm{C}$ and varied from $0^{\circ} \mathrm{C}$ in January to $27.1^{\circ} \mathrm{C}$ in August during the present study. The Lake fed by underground and rain water, in spring months excess lake water is discharged by a small chanel to Sakarya River (Altınsaçlı et al., 2014).

\section{Fish sampling and parasitological analysis}

A total of 61 white bream $B$. bjoerkna specimens (20 males and 41 females) were examined between July 2016 and June 2017. They had a mean ( \pm SD) total length of $21.0 \pm 2.8 \mathrm{~cm}$ (range 15.9-28.3 cm) and a mean ( $\mathbf{S} \mathrm{SD}$ ) weight of $111.1 \pm$ $48.4 \mathrm{~g}$ (range $48.6-178.9 \mathrm{~g}$ ). Fish were caught using gillnets with a knot to knot mesh size of 10,20 and $30 \mathrm{~mm}$. Nets were $50 \mathrm{~m}$ long with a $1.5 \mathrm{~m}$ hanging depth and cast net. The fish were transported to the laboratory alive, anesthetized with 100 $\mathrm{mg} / \mathrm{l}$ buffered Tricaine Methane Sulfonate (MS-222), weighed and measured. The sex of each individual was determined by visual and microscopic examination of the gonads. The fish were necropsied as soon as possible; the external surfaces of the body, gills, eyes and internal organs were examined separately.

Wet smears of skin and gills were prepared and examined in order to detect the presence of protozoan parasites. Monogenean parasites were removed and placed on a slide with ammonium picrate-glycerine or lactophenol and covered with a cover-glass, and flat mounts were prepared. Trematode and cestode specimens were identified alive or fixed in $70 \%$ alcohol. Parasites were stained in acetocarmine, dehydrated through an alcohol series, cleared in dimethyl phthalate and examined as permanent mounts in Canada balsam. Most of these parasite specimens were slightly flattened before fixation. Crustacean parasites were cleared in lactophenol and mounted in Canada balsam. Slides were studied with a microscope at $40 x$ and $100 x$ magnification.

\section{Statistical analysis}

The prevalence, mean intensity and abundance of the parasite species were determined as defined by Bush et al., (1997). Kruskal Wallis H Test were used to compare species richness and parasite effect on fish condition factor. Mann Whitney $U$ Test was used to compare differences in mean number of parasite species between male and female fish. The following indices were used to characterise the parasite communities: the Berger-Parker dominance index, $d=n_{\max } / \mathrm{N}$; the Shannon-Wiener species diversity index, $H^{\prime}=-\Sigma($ pix $\mid n$ pi); the Simpson index, $\mathrm{D}=\Sigma \mathrm{ni}(\mathrm{ni}-1) / \mathrm{N}(\mathrm{N}-1)$; an index of evenness $=$ $\mathrm{H} / \mathrm{H}_{\max }$. Parasites recovered were fixed and preserved according to Bylund et al., (1980). Parasite species were identified according to Lom and Dykova (1992), Niewiadomska (2003), Pugachev et al., (2010) and Bykhovskaya-Pavlovskaya et al., (1962).

\section{RESULTS}

A total of 61 Blicca bjoerkna specimens were examined; all of the fish hosts were parasitised by at least one parasite species and a total of 2063 individuals of metazoan parasites were collected in or on the fish hosts. Totally 16 parasite species were identified from the following taxa; Trichodina sp., Epistylis sp. (Protozoa); Myxobolus sp. (Myxozoa); Dactylogyrus sphyrna, D. cornu, D.cornoides, D. distinguendus and Paradiplozoon homoion (Monogenea); Caryophyllaeus laticeps and Cestoda gen. sp. (Cestoidea); Diplostomum sp., Thylodelphys clavata and Posthodiplostomum cuticola (Digenea); Piscicola geometra (Hirudinea); Glochidium sp. (Mollusca) and Argulus foliaceus (Crustacea), (Figs. 2-7). The infra-communities consisted of 1-10 parasite species, overall, $3.3 \%$ were parasitised by one species, $6.6 \%$ by two, $26.2 \%$ by five parasite species (Figure 1).

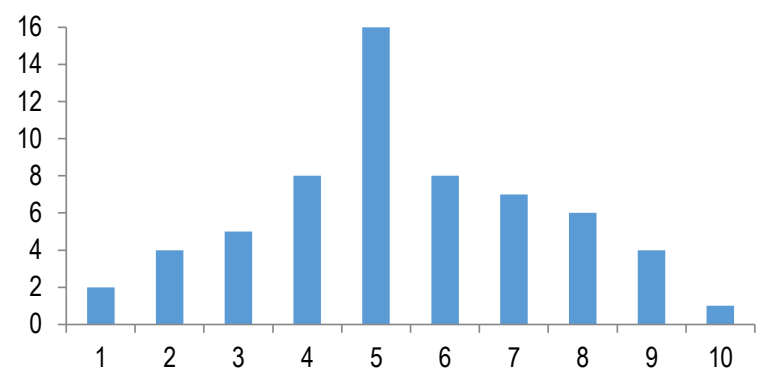

Figure 1. Frequency distribution of the number of parasite species in Blicca bjoerkna from Lake Büyük Akgöl

Dominant species in the component communities were Diplostomum sp., D. cornoides, and D. cornu. The most prevalent parasites were Diplostomum sp. $(78.7 \%), D$. cornoides (68.9\%), D. cornu (67.2\%) and D. sphyrna (63.9\%). The epidemiological parameters of infection by parasites of $B$. bjoerkna are given in (Table 1). 
Table 1. Infection parameters of Blicca bjoerkna from Lake Büyük Akgöl ( $n=61)$

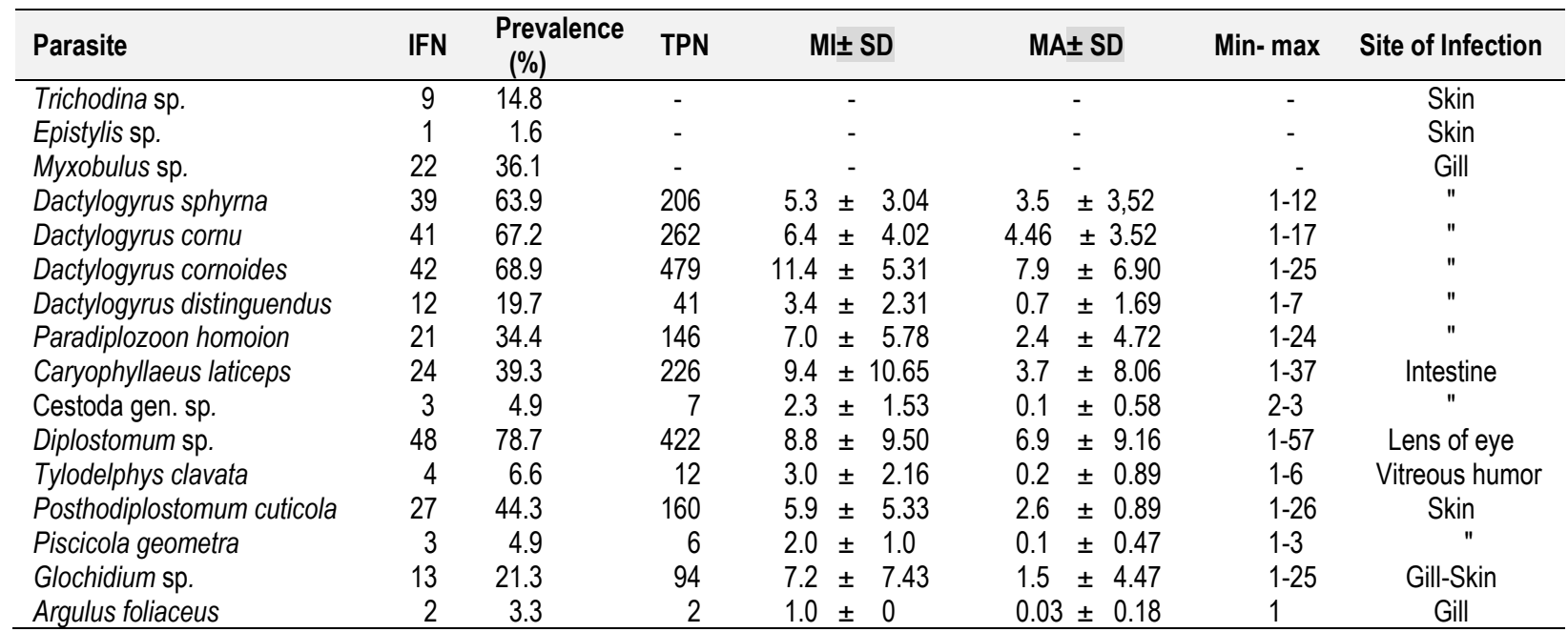

IFN: Infected Fish Number; TPN: Total Parasite Number; MI: Mean Intensity; MA: Mean Abundance

The highest dominance index of the metazoan parasites was recorded for $D$. cornoides (23.2\%), and the lowest for $A$. foliaceus $(0.1 \%)$; the dominance index (D) values of the parasite species are given in (Table 2).

Table 2. Dominance index of the metazoan parasites in Blicca bjoerkna from Lake Büyük Akgöl

\begin{tabular}{lc}
\hline Parasite Species & $\begin{array}{c}\text { Dominance index D } \\
(\%)\end{array}$ \\
\hline Dactylogyrus sphyrna & 10.0 \\
Dactylogyrus cornu & 12.7 \\
Dactylogyrus cornoides & 23.2 \\
Dactylogyrus & 2.0 \\
distinguendus & 7.1 \\
Paradiplozoon homoion & 11.0 \\
Caryophyllaeus laticeps & 0.3 \\
Cestoda gen. sp. & 20.5 \\
Diplostomum sp. & 0.6 \\
Tylodelphys clavata & 7.7 \\
Posthodiplostomum & 0.3 \\
cuticola & 4.5 \\
Piscicola geometra & 0.1 \\
Glochidium sp. & \\
Argulus foliaceus & \\
\hline
\end{tabular}

The mean parasite diversity (Shannon's $\mathrm{H}$ index) was 2.08 and the Shannon-Wiener Evenness $(E)$ had a mean value of 0.81 . Diversity indices of the parasite community of Blicca bjoerkna from Lake Büyük Akgöl are given in (Table 3). The mean number of parasite species richness per host individual (mean infracommunity richness) found was 5.3 and this value increased from 5 in $(15.0-16.9 \mathrm{~cm})$ size class to 6.2 in $23.0 \mathrm{~cm}$
$>$ size class and no significant differences were found (Kruskal Wallis $H$ test $p>0.05$ ). Also, the mean numbers of parasite species in male and female fish hosts were found to be 4.4 and 5.8 respectively with significant differences observed (MannWhitney $\mathrm{U}$ test $\mathrm{p}<0.05$ ). The condition factor from each size group was computed to analyse the influence of the parasites on fish condition and no significant differences were found (Kruskal Wallis $H$ test $p>0.05$ ). Higher prevalence and mean intensity for Dactylogyrus cornu and $D$. cornoides were found in March and April whereas D. sphyrna reached high prevalence and mean intensity in February. Distribution of other most prevalent parasite Diplostomum sp. was highly homogenous. Monthly prevalence and mean intensity of the parasites are given in (Table 4).

Table 3. Diversity indices of the metazoan parasites of Blicca bjoerkna in Lake Büyük Akgöl

\begin{tabular}{ll}
\hline Diversity Indices & \\
\hline Number of white bream & 61 \\
Number of metazoan taxa & 13 \\
Species richness & 16 \\
Shannon-Wiener Index & 2.08 \\
Shannon-Wiener Evenness & 0.81 \\
Simpson's Diversity & 0.85 \\
Dominant taxon & Dactylogyrus cornoides \\
\hline
\end{tabular}




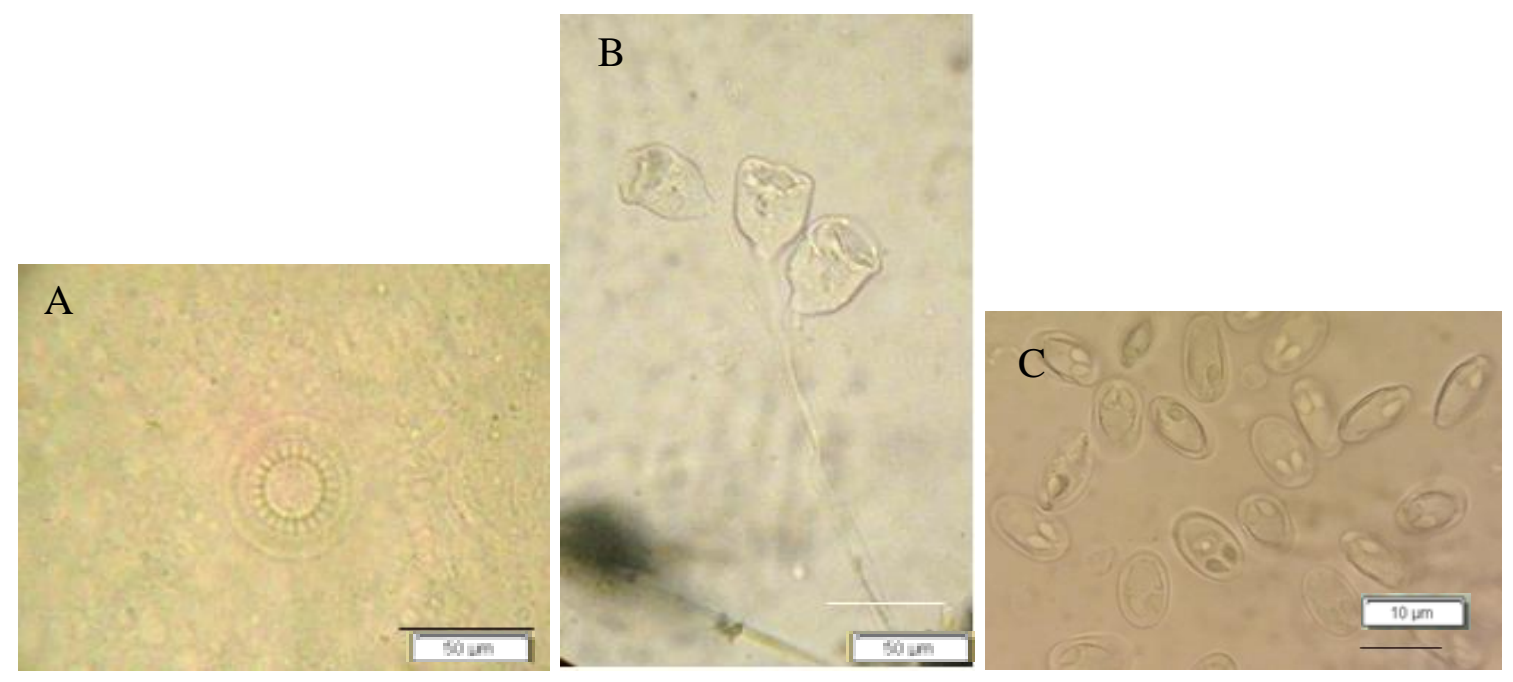

Figure 2. A. Trichodina sp., B. Epistylis sp., C. Myxobolus sp.

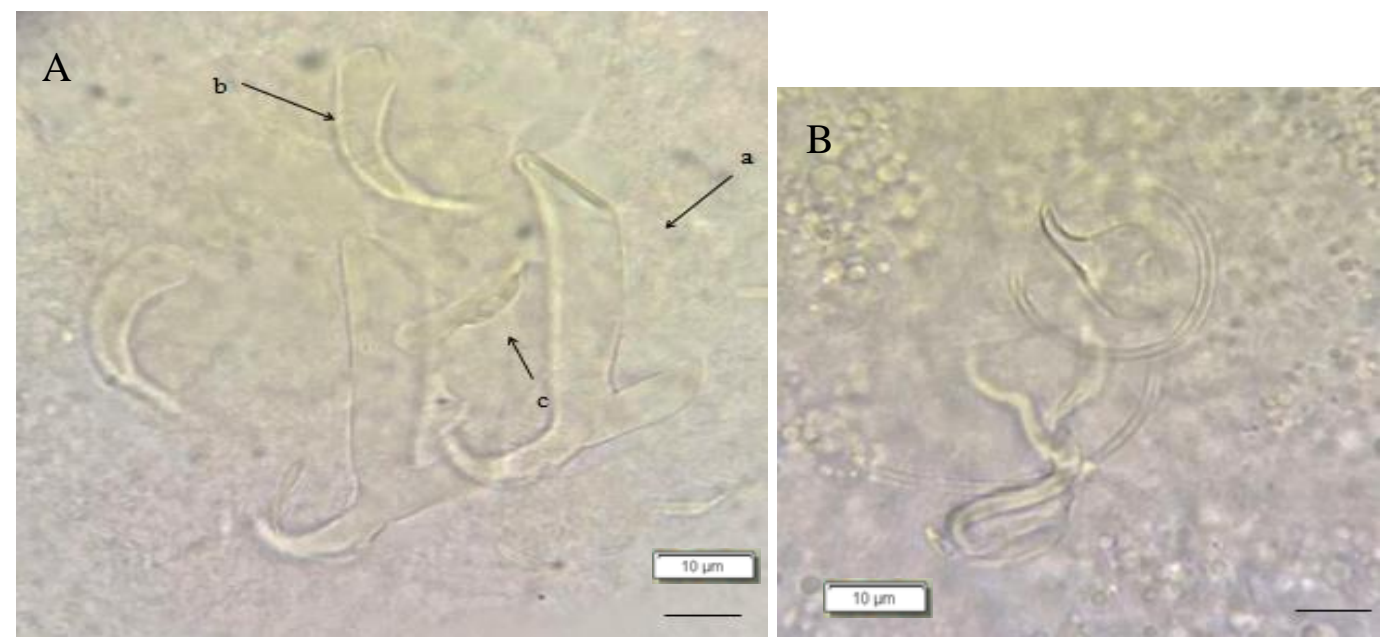

Figure 3. Dactylogyrus sphyrna A. haptor, a. anchor b. third pair of marginal hook c. bar, B. copulatory organ

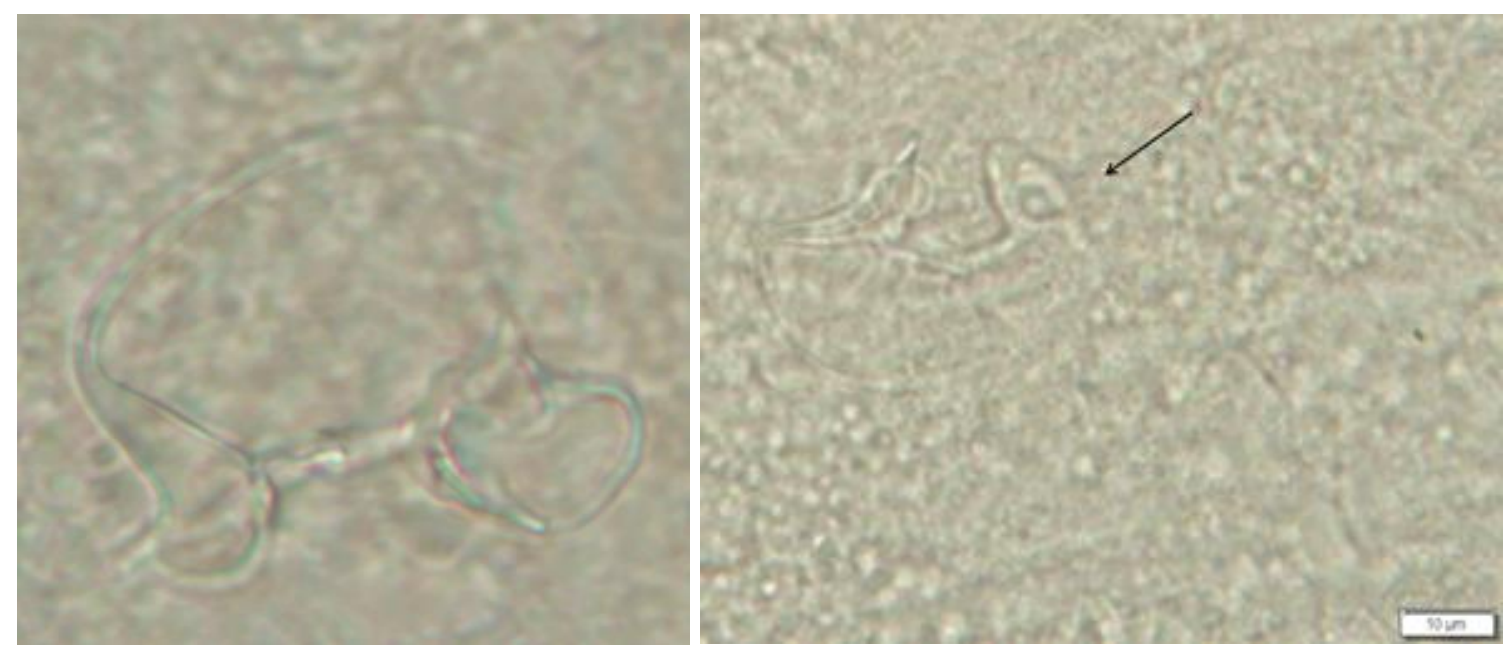

Figure 4. A. Dactylogyrus cornu, B. Dactylogyrus cornoides copulatory organs 

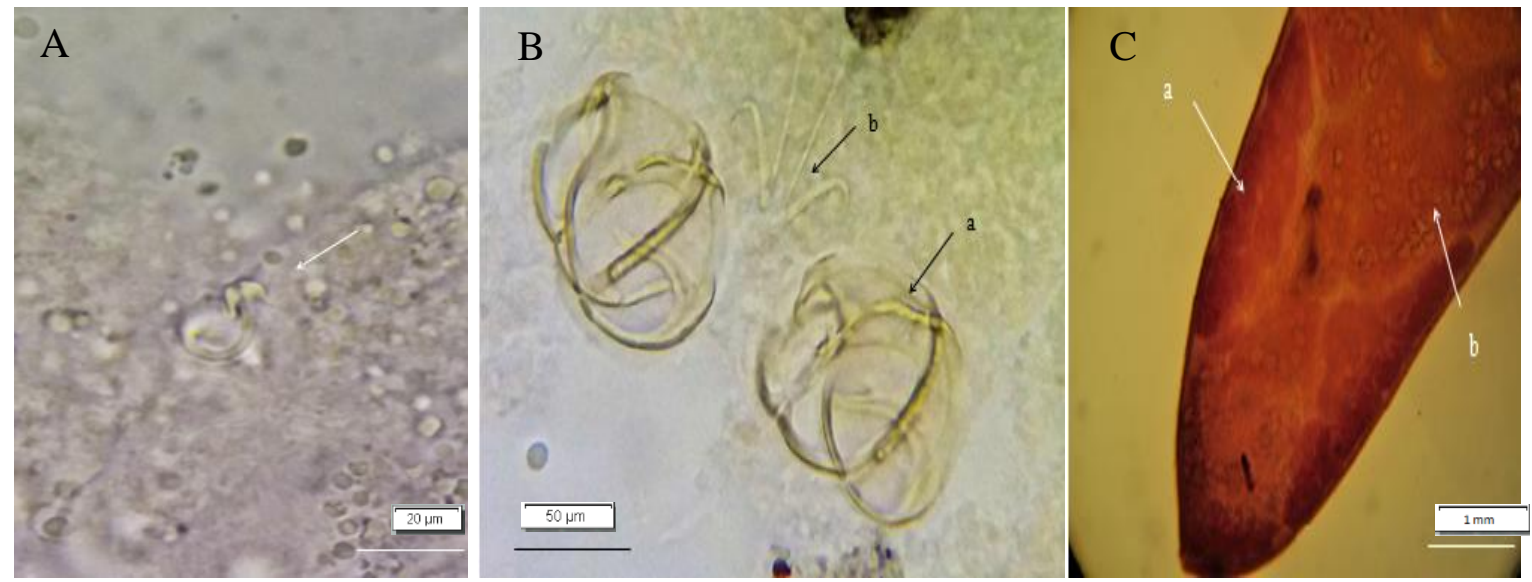

Figure 5. A. Dactylogyrus distinguendus vaginal tube, B. Paradiplozoon homoion a. clamp b. anchors. C. Caryophyllaeus laticeps a. ovary b. vitelline follicles.
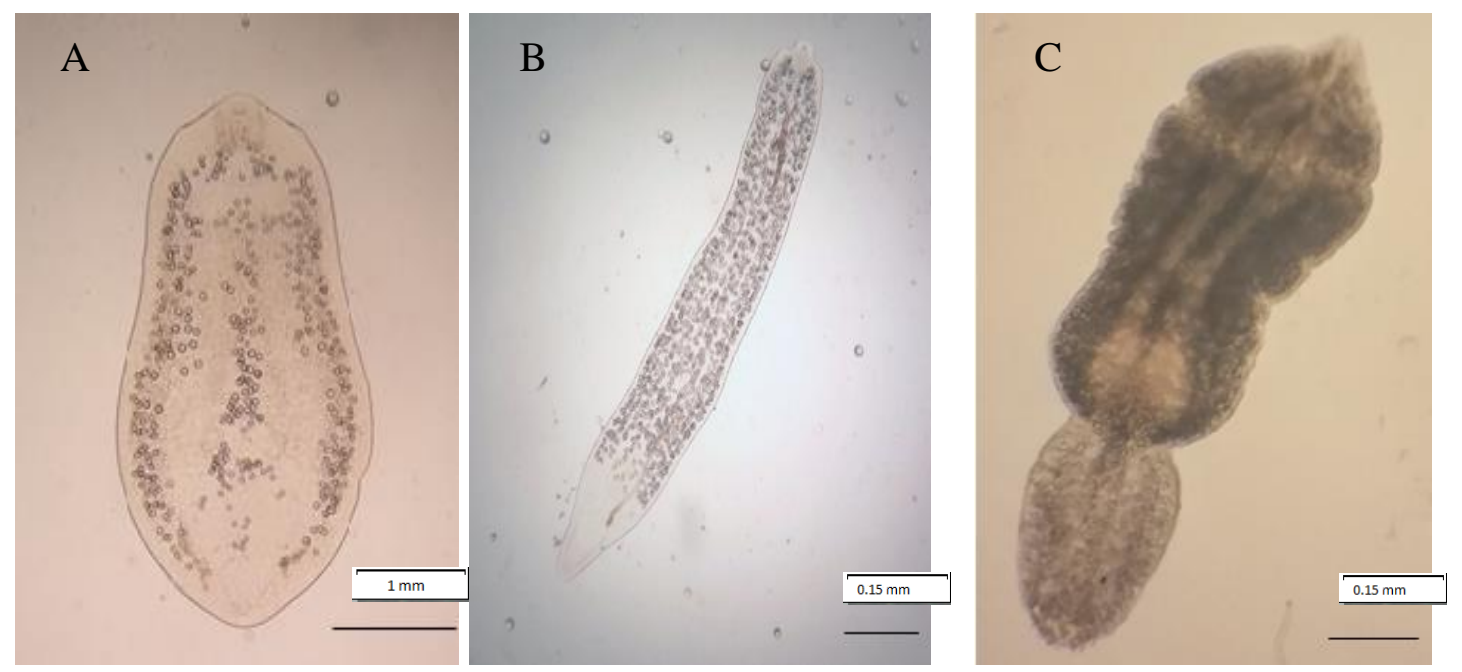

Figure 6. A. Diplostomum sp., B. Thylodelphys clavata, C. Posthodiplostomum cuticola
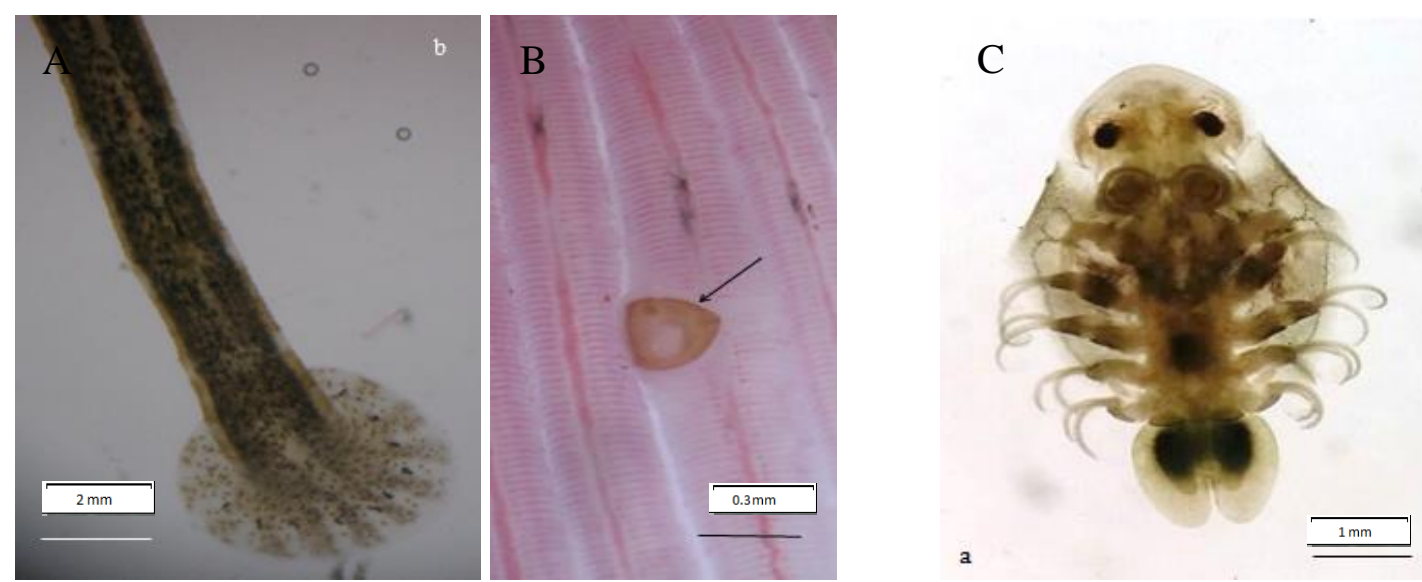

Figure 7. A. Piscicola geometra posterior end, B. Glochidium sp., C. Argulus foliaceus 
Table 4. Monthly prevalence and mean intensity of the parasites in Blicca bjoerkna from Lake Büyük Akgöl

\begin{tabular}{|c|c|c|c|c|c|c|c|c|c|c|c|}
\hline \multirow[t]{2}{*}{ Parasite Species } & \multicolumn{2}{|c|}{ December } & \multicolumn{2}{|c|}{ February } & \multicolumn{2}{|c|}{ March } & \multirow{2}{*}{$\begin{array}{c}\text { April } \\
\mathrm{P}(\%) \mathrm{Ml}\end{array}$} & \multicolumn{2}{|c|}{ May } & \multicolumn{2}{|c|}{ June } \\
\hline & $\mathbf{P}(\%$ & MI & $\mathrm{P}(\%)$ & MI & $P(\%)$ & $\mathrm{MI}$ & & $\mathbf{P}(\%$ & MI & $\mathbf{P}(\%)$ & MI \\
\hline D.sphyrna & 25 & 2 & 84.7 & 6.8 & 73.9 & 3.4 & 44.47 .5 & 25 & 8.5 & 100 & 6.5 \\
\hline D.cornu & & & 53.8 & 7.4 & 73.9 & 5.5 & 88.910 .9 & 62.5 & 4.4 & 100 & 4 \\
\hline D.cornoides & & & 69.2 & 9.5 & 69.5 & 10.1 & 88.98 .1 & 50 & 9.5 & 100 & 10 \\
\hline D.distinguendus & & & 7.7 & 3 & 34.8 & 3 & 22.26 & & & & \\
\hline Paradiplozoon homoion & & & & & & & $44.4 \quad 5.7$ & 100 & 9.9 & & \\
\hline Caryophyllaeus laticeps & & & 46.1 & 2.5 & 65.2 & 11 & $66.7 \quad 9.8$ & & & & \\
\hline Cestoda gen. sp. & & & & & & & 11.12 & 25 & 2.5 & & \\
\hline Diplostomum sp. & 100 & 15.2 & 69.2 & 10.2 & 100 & 6.2 & 88.915 & 75 & 5.3 & 100 & 16 \\
\hline Tylodelpyhs clavata & 100 & 3.3 & 7.7 & 1 & 4.3 & 1 & & & & & \\
\hline Posthodiplostomum cuticola & & & 38.5 & 3.6 & 65.2 & 5 & 55.511 .4 & 11.1 & 4.0 & 75 & 5 \\
\hline Pisciola geometra & & & 7.7 & 1 & & & & & & & \\
\hline Glochidium sp. & 50 & 3 & 7.7 & 5 & & & 88.911 .3 & 75 & 6.3 & & \\
\hline Argulus foliaceus & & & & & & & & & & 25 & 2 \\
\hline
\end{tabular}

P: Prevalence; MI: Mean Intensity

\section{DISCUSSION}

The present paper is a first-time study of parasites communities infecting B. bjoerkna from Lake Büyük Akgöl. When the water level is high at the end of winter, the Lake is connected by a canal to Sakarya River. On the other hand nearby Lake Sapanca, during spring months release excess water into Sakarya River. Soylu $(1991,2006)$ recorded $D$. cornu, D. cornoides, D. sphyrna, D. distinguendus, Bothriocephalus acheilognathi, Aspidogaster limacoides, Asymphylodora imitans, Tetracotyl sp., Diplostomum sp., Tylodelphys clavata, Posthodiplostomum cuticola and Glochidium sp. in B. bjoerkna from oligotrophic Lake Sapanca. Akmirza and Yardımcı (2014) found Trichodina sp., Paradiplozoon homoion, Allocreadium lobatum, Caryophyllaeus laticeps and Glochidium sp. in B. bjoerkna from Sakarya River. Naturally, there are similarities between parasite communities of $B$. bjoerkna from these three related aquatic environments. But there are also some differences, in Lake Büyük Akgöl, no intestinal digeneans, acanthocephalan and nematodes were found in $B$. bjoerkna, despite this fish infected by three intestinal digeneans in Lake Sapanca. A parasitological survey conducted in Kocadere Stream, Bursa on B. bjoerkna by Selver et al. (2010) and five parasite species identified. The overall prevalence of parasitic infection in this lotic environment were Dactylogyrus sphyrna $24.2 \%, D$. distinguendus 30.8\%, Diplostomum spathaceum 95.8\%, C. laticeps $2.5 \%$ and Eustronglydes sp. $8.3 \%$. Similar parasitological investigation on B. bjoerkna performed in Anzali Lagoon, Caspian Sea Iran by Pazooki et al. (2011) and 11 parasite species found. Identical parasite species from Anzali with our study and their overall prevalence are Trichodina perforate $53.9 \%$, Myxobolus musayevi $27.2 \%$, D. sphyrna $5.2 \%$, D. spathaceum $98.7 \%$ and P. cuticola $15.4 \%$. In Anzali Lagoon only one and in Kocadere Stream two monogenean species recorded, however in the present study five monogenean species identified. D. sphyrna has highest prevalence in our study with $63.9 \%$. In three studies Diplostomum recorded in high percentage. Differently than these two studies we could not find nematodes. According to Wisniewski (1958) character of a water body, especially its trophic status influenced and determined composition of parasite species. Toxic pollutants were effective on the freeliving stage of parasites and reduced their infectivity and longevity of cercariae. Parasites with indirect life cycles are linked more tightly to the presence of intermediate hosts. The prevalence of digeneans in their intermediate and definitive hosts is inversely related to the degree of pollution and disturbance of aquatic ecosystems (Sures et al., 2017). The species composition of parasite communities is clearly impacted by environmental stress and species richness tends to decrease under degraded conditions (Marcoglies, 2005). Absence of intestinal digenean, acanthocephalan and nematodes in the present study is connected to heavy polluted conditions of the lake. During summer and autumn months accompanied by hypereutrophy and minimum water level, dissolved oxygen measured at bottom and surface of the lake were 0.17 and $0.93 \mathrm{mg} / \mathrm{l}$ respectively (Şengörür and Demirel, 2002). Drainage waters that flow from irrigated fields bring fertilizers and pesticides into the lake.

The most common elements of zoobenthic biomass were three dominant taxa: Gastropoda, Chironomidae, and Oligochaeta (Aras, 2011). Viviparus viviparus, Lynnea stagnalis, Borysthenia naticina and Planorbarius corneus are dominant gastropod species as intermediate host of digeneans that has a wide range of tolerance to different environmental conditions. But two pulmonats; Gyraulus sp., and Radix labiata (bioindicator species for pollution) were very scarce. Caryophyllaeus laticeps was one of the most prevalent parasites in Blicca bjoerkna and intermediate host Potamothrix hammoniensis is dominant oligochaet in the lake benthos. 
Aquatic tubificid oligochaetes known as the intermediate host of C. laticeps Mackiewicz (1994) is common on benthic fauna of Lake Büyük Akgöl and is pollution tolerant. Proclaidus sp., Chironomus plumosus and $C$. tentans are also dominant chironomids Aras (2011), that are tolerant organisms to pollution (Taşdemir et al., 2010). In Lake Büyük Akgöl, annual mean concentration of $\mathrm{Pb}, \mathrm{Cu}, \mathrm{Cr}$ and $\mathrm{Cd}$ exceeded the alert limit (Aras, 2011). Monogeneans were the most abundant species in parasite component communities of $B$. bjoerkna. Dzika (2003) specified that the structure of a parasite community, where monogeneans are a dominant component, indicates a high eutrophication. Koskivaara (1992) found the highest density of Dactylogyrus parasites in the most eutrophied and polluted Vatia Lake. In the current study, the lowest mean abundance value of glochidium sp. (1.5 individual per fish) was associated with distorted lake conditions. Anthropogenic disturbances, including pollution are the major factors driving changes in freshwater mussels and listed as

\section{REFERENCES}

Akmirza, A. \& Yardımcı, R.E. (2014). Fish Parasites of the Sakarya River, Turkey. Journal of Academic Documents for Fisheries and Aquaculture 1 23-29. ISSN: 2148-2608.

Akıncı, A.G. (1999). Identification of platyhelminth parasites of the white bream (Blicca bjoerkna L. 1758, Cyprinidae) from Lake Uluabat (Apolyont). Bursa Uludağ University, Institute for Graduate Studies in Pure and Applied Sciences, Master's thesis 34pp.

Altınsaçlı, S., Altınsaçlı, S. \& Temel, M. (2013). Species composition and qualitative distribution of macrophytes in four lakes (Karasu, Adapazarı, Turkey). Phytologia Balcanica, 19, 67-75

Altınsaçı, S., Altınsaçlı, S. \& Paçal, F.P. (2014). Species composition and distribution of ostracods (Crustacea, Ostracoda) in some lakes and lagoons (Kocaeli and Sakarya, Turkey). Journal of Entomology and Zoology Studies, 2 , 182-192.

Aras, S. (2011). Macrozoobenthic Limnofauna (Gastropoda, Oligochaeta Chironomidae) of Lake Büyük Akgöl (Adapazarı) and accumulation of macro and microelements in biotic and abiotic components. Eskişehir Osmangazi University, Institute for Graduate Studies in Pure and Applied Sciences, Ph D Thesis $128 \mathrm{pp}$.

Bush, A.O., Lafferty, K.D., Lotz, J.M. \& Shostak, A.W. (1997). Parasitology meets ecology on its own terms: Margolis et al. revisited. Journal of Parasitology 83, 575-583. DOI: 10.2307/3284227

Bykhovskaya-Pavlovskaya, I. E., Gussev, A.V., Dubinina, M.N., Izyumova, N.A., Simirnova, T. S., Sokolovskaya, I., Shtein, G.A., Shulman, S. \& Epshtein, V.M. (1962). Key to parasites of freshwater fish of the USSR. Izdatelsvi Akademi Nauk SSSR. Moskva Leningrad (Translated from Russian, Israel Program for Scientific Translation, Jerusalem).

Bylund, G., Fagerholm, H.P., Calenius, G., Wikgren, B.J. \& Wikström, M. (1980). Parasites of fish in Finland. II. Methods for studying parasite fauna in fish. Acta Academiae Aboensis Series B 40, 23 pp.

Dzika, E. (2003). Parasites of roach, Rutilus rutilus (L.), in lakes of the Masuria Lake I and as indicator of the quality of aquatic environment. Wydawnic two UWM Olsztyn, (In Polish).

Geldiay, R. \& Balık, S. (1988). Freshwater fishes of Turkey. Faculty of Science, Ege University, Set of books. Nr: 97.

Keller, A.E. \& Zam, S.G. (1991). The acute toxicity of selected metals to the freshwater mussel, Anodonta imbecilis. Environmental Toxicology and Chemistry 10, 539-546. DOI: 10.1002/etc.5620100415 threatened or endangered species in some countries (Keller and Zam, 1991; Nobles and Zhang, 2015). Many mussel species are relatively intolerant of elevated nutrient and toxin concentrations, especially during their larval and juvenile life stages (Valenti et al., 2006).

In conclusion, Monogenea were the most common parasitic group encountered with 16 species found. Identified parasite species of $B$.bjoerkna and their intermediate hosts are pollution tolerant organisms. Intestinal digenean, acanthocephalan and nematodes were not found in $B$. bjoerkna from this heavily polluted lake.

\section{ACKNOWLEDGEMENTS}

This article was extracted from a Master's thesis conducted at the Institute for Graduate Studies in Pure and Applied Sciences, Marmara University. We would like to thank Konacık Village Fishermen's Cooperative for their assistance.

Koskivaara, M. (1992). Environmental factors affecting monogeneans parasitic on freshwater fishes. Parasitology Today 8, $339-341$. DOI: 10.1016/0169-4758(92)90069-E

Krebs, C. J. (1999). Ecological methodology. 2d ed. AddisonWesley, Boston. ISBN-13: 978-0321021731

Lom, J., \& Dykova, I. (1992). Protozoan parasites of fishes. Series: Developments in Aquaculture and Fisheries Science. Elsevier, Amsterdam, 315 pp. ISBN : 0444894349

Mackiewicz, J.S. (1994). Order Caryophyllidea van Beneden in Carus, 1863. In Khalil, L.F., Jones, A., Bray R.A. (Eds) Keys to the cestode parasites of vertebrates. CAB International, Wallingford, UK, pp. $21-43$.

Marcogliese, D.J. (2005). Parasites of the superorganism: Are they indicators of ecosystem health? International Journal for Parasitology 35, 705-716. DOI:10.1016/j.ijpara.2005.01.015

Niewiadomska, K. (2003). The parasites of Polish fish (key to species identification). The flukes-Digenea. Warszawa: P.T.P., pp. 169.

Nobles, T \& Zhang, Y. (2015). Survival, growth and condition of freshwater mussels: Effects of municipal wastewater effluent. PLos One. 10. E0128488. DOI: 10.1371/journal.pone.0128488

Öztürk, M.O. \& Altunel, F.N. (2001). The occurrence of cestodes in four species (Blicca bjoerkna, Rutilus rutilus, Scardinius erythrophthalmus, Vimba vimba) of Cyprinidae from Manyas Lake. Veterinary Journal of Ankara University 48, 43-50.

Pazooki, J., Goorabzarmakhi, F.T. \& Masoumian, M. (2011). Parasitic Infection of an Endemic Fish (Blicca bjoerkna) and an Exotic Fish (Hemiculter beucisculus) In Anzali Lagoon, Caspian Sea, Iran. Iran Journal of Parasitology. 6, 66-73.

Poulin, R. (1996). Patterns in the evenness of gastrointestinal helminth communities. International Journal for Parasitology 26,181-186. DOI: 10.1016/0020-7519(95)00112-3

Poulin, R., Luque, J.L. F. Guilhaumon, F. \& Mouillot, D. (2008). Species abundance distributions and numerical dominance in gastrointestinal helminth communities of fish hosts. Journal of Helminthology, 82, 193202. DOI:10.1017/S0022149X08982626

Pugachev, O.N., Gerasev, P.I., Gussev, A.V., Ergens, R. \& Khotenowsky I. (2010). Guide to Monogenoidea of freshwater fish of Palaeartic and Amur regions. (Scientific Editors: Pugachev O.N., P. Galli and D.Kristsky). 567pp. ISBN 978-88-95994-10-9. 
Selver M.M., Aydoğdu A.I. \& Cırak V.Y. (2010). Helminth parasites of white bream (Blicca bjoerkna L. 1758) from Kocadere Stream, Bursa. Acta Parasitologica Turcica 34, $118-121$

Soylu, E. (1991). Monogeneans of some fishes from Lake Sapanca. Istanbul University Institute of Marine Sciences and Geography Bulletin 8, 145-156.

Soylu, E. (2006). Some metazoan parasites (Cestoda, Trematoda and Mollusca) of Blicca bjoerkna Linnaeus, 1758 from Sapanca Lake, Turkey. Istanbul University Journal of Fisheries \& Aquatic Sciences 20, 51-62.

Soylu, E. (2012). Monogenean parasites of white bream (Blicca bjoerkna Linnaeus, 1758) in Lake Sapanca, Turkey. Journal of the Faculty of Veterinary Medicine, Kafkas University 18 (Suppl-A): A23-A28. DOI: 10.9775/kvfd.2011.5239

Stirling, G., \& Wilsey, B. (2001). Empirical relationships between species richness, evenness, and proportional diversity. American Naturalist, 158 286-299. DOI:10.1086/321317

Sures, B., Nachev, M., Selbach, C. \& Marcogliese, D.J. (2017). Parasite responses to pollution: what we know and where we go in 'Environmental Parasitology Parasites \& Vectors, 6,65 DOI: 10.1186/s13071-017-2001-3
Sahin, A.P, Morkoyunlu, Y.A. \& Soylu, E. (2013). Composition and seasonal changes of phytoplankton in Lake Büyük Akgöl (Sakarya). Journal of Eğirdir Fisheries Faculty 9: 14-21. E-ISSN: 1308-7517.

Şengörür, B. \& Demirel, A. (2002). Eutrophication in Akgöl (Gölkent-Sakarya) and water quality classification. Sakarya University Journal of Science, 6 , $1-8$

Taşdemir, A., Ustaoğlu, M.R. \& Balık, S. (2010). The Chironomidae (DipteraInsecta) fauna of Yuvarlakçay Stream (Köyceğiz-Muğla-Turkey). Ege University Journal of Fisheries \& Aquatic Sciences 27, 61-64. ISSN 1300 $-1590$.

Valenti, T.W., Cherry, D.S., Currie, R.J., Neves, R.J., Jones, J.W. \& Mair, R. (2006). Chlorine toxicity to early life stages of freshwater mussels (Bivalvia: Unionidae). Environmental Toxicology and Chemistry 25, 25122518. PMID:16986807

Wisniewski, W.L. (1958). Characterization of the parasitofauna of an eutrophic lake (parasitofauna of the biocoenosis of Druzno Lake. Part I). Acta Parasitologica Polonica. 6, 1-64. 